\title{
SOKAL'S HERMENEUTIC HOAX: PHYSICS AND THE NEW INQUISITION
}

Babette Babich

Fordham University, babich@fordham.edu

Follow this and additional works at: https://fordham.bepress.com/phil_research

Part of the Continental Philosophy Commons, Philosophy of Science Commons, and the Rhetoric Commons

\section{Recommended Citation}

Babich, Babette, "SOKAL'S HERMENEUTIC HOAX: PHYSICS AND THE NEW INQUISITION" (2001). Research Resources. 20. https://fordham.bepress.com/phil_research/20

This Article is brought to you for free and open access by the Hermeneutic and Phenomenological Philosophies of Science at DigitalResearch@Fordham. It has been accepted for inclusion in Research Resources by an authorized administrator of DigitalResearch@Fordham.

For more information, please contact considine@fordham.edu. 


\section{BABETTE E. BABICH}

\section{SOKAL'S HERMENEUTIC HOAX: PHYSICS AND THE NEW INQUISITION}

As a so-called post-analytic philosopher of science, ${ }^{1}$ if also from the marginalized sidelines, I have been able to tease analytic philosophers, calling them to account for their desire to imitate scientists and their habit of numbering their paragraphs and their passion for the acronym. Much more seriously, the scientists themselves have recently begun to raise the ante for analytic philosophers in the so-called science wars. In essays and op-ed pieces, physicists are repaying the philosophers' compliment - not only by adopting, as popular science writers have long done, the role of cultural critic, but also by assuming the mantle of philosophy. Science, once the arbiter of scientific truth, proposes now to vet the truth about everything else. And analytic philosophy of science has found itself faced with no less uncritical option than blanket applause.

In May of 1996, Alan Sokal, a New York University physicist, submitted an inauthentic article to the journal Social Text. ${ }^{2}$ Its inauthenticity, in Sokal's mind, consisted in his pretending to articulate the political and philosophical implications of recent physics research relevant to various theorems of cultural criticism (multiculturalism or pluralism, deconstructive indeterminacy, and the valorization of feminist or gender-open logical schemes). Next, in Lingua Franca, a journal devoted to academic gossip and scandal, Sokal published a brief retraction. ${ }^{3}$ Sokal's first article (in $S T$ ) was bogus, ${ }^{4}$ the second (in $L F$ ) explained why. For the world of academic publishing, it seemed scandalous that the editors of $S T$ failed (or pretended to fail) to notice that the parallels he detailed between the results of recent physics research were "nonsense." Sokal, for his own part, regarded his effort as "parodic."

In other words, and we do need to invoke other words here, it is possible to define Sokal's $S T$ article as a parody (as Sokal insists) because the author was lying when he wrote what he wrote. He did not mean it, as children say. But Sokal's definition of parody is idiosyncratically superficial. Like a hoax or the related but just as banal genre of the practical joke, the $S T$ article required a complementary supplement in order to be properly decoded. Thus Sokal's LF text retracted his ST text, deconstructing it as less than earnestly intended - a coreferentiality reinforcing the plausibility of the hypothesis that Sokal also enjoyed an "in" assured not only by his own authority as a physicist, but by the lead ST editor himself where the complicity of the LF editors may for their part be assumed. The difference between the parody Sokal composed and what

67

B. E. Babich (ed..), Philosophy of Science, Van Gogh's Eyes, and God: Hermeneutic Essays in Honor of Patrick A. Heelan, S.J., 67-78.

(C) 2001 Kluwer Academic Publishers. Printed in the Netherlands. 
ordinarily counts as parody or satire is the difference between Jerry Seinfeld and Jonathan Swift. Yet it is asserted again and again, much like the populace's response to their naturalist emperor's new clothes, that Sokal's ruse is uproariously funny. ${ }^{5}$ Sokal, we are given to believe, is a great laugh for those who are in on the joke, or more accurately, those who aspire to be thought of as in on the joke. ${ }^{6}$ Accordingly, popular science writers, physicists and others, but above all practitioners of the philosophy of science have been united in their convicted assertions of appreciative resonance. The general response thus continues to be a strikingly uniform affirmation of the amusement value of the "hoax" as amusing - even worthy of "awe" in the case of Peter Caws. ${ }^{7}$ Even Mara Beller's critical perspective does not deny but only proposes to deepen the target and the consequences to be drawn from the joke. ${ }^{8}$

Parody or prank, classification of Sokal's game is hardly the issue. The stunt, the sheer achievement of it (I suppose this is what drew Caws's good philosophical breath), is the thing. A number of attacks and counterattacks have been proffered, mostly, as with Steven Weinberg's vigorous effort, ${ }^{9}$ on behalf of the prankster - for who among philosophers of science would willingly assume the part of the dupe? The only defenses on offer are those from the side of Social Text's editors, and none of these take more than an overly legalistic tack in charging "science fraud." Science, they tell us, "ought" to play fair and Sokal, they tell us, right though he is, ought to have known better. Other, embarrassingly irrelevant, defenses follow the thematics, though occasionally correcting the schematic flaws, of Stanley Fish's uninflected and less than tactful argument in the New York Times. ${ }^{10}$ Better defenses, like Dorothy Nellkin's essay in the Chronicle of Higher Education, analyze the science wars in terms of desperate scientists seeking scapegoats to blame for the economic troubles in which they now find themselves, while Nelkin advises against the long-term efficiency of divisive academic bickering. ${ }^{11}$ Defenses of $S T$ offered from the left likewise, and this is important to emphasize, assume the accuracy of all charges raised (one ought to have invited "peer" - i.e., other physicists' - reviews) and, as accurately summarized in Ellen Willis's Village Voice essay, recall the scrambling for credit among extremist groups in the wake of a terrorist attack. ${ }^{12}$ Thus most of the reviews concur with Sokal's fundamental claim: Eliminate unclarity and all will be clear in (science) love and (science) war. And Willis herself, decidedly on the left and writing for the defense, decries the fuzziness of "pomo lingo" and the "hermetic verbiage ... covering up muddled thinking," Weinberg, on the right and on the attack, is no less confident in his claim that physics prose (he is thinking of the theory of special relativity) is clearly written, whereas philosophical expression (he invokes Jacques Derrida, other authors on the clarity rampage name Theodore Adorno, himself a dedicated opponent of jargon - and who will ask what to make of this? - and who will draw the still-needed connection that remains to be articulated between Derrida and Adorno, refracted via Husserl's Origin of Geometry?) is not. ${ }^{13}$ If $\mathrm{W}$ einberg is compelled to refrain from citing physics prose per se to make his point, that is because, as he affirms, physics naturally requires technical terminology while philosophy requires no such terminology and has no comparable training prerequisites. ${ }^{14}$ The leftist contingent asserts this same imperative, which conveniently reflects the stylistic mandate of establishment analytic philosophy. Ah, well, sigh the intellectuals who ought to know better, if only things were said simply and plainly, clearly and distinctly, we would then have the truth. This is a popular and democratic 


\section{SOKAL’S HOAX: PHYSICS AND THE NEW INQUISITION}

ideal. But we need to ask, as Nietzsche once did, is truth simple? ${ }^{15}$ Better go further and ask, Is anything simple?

The conviction about which the science wars are fought is that there exists a wellestablished, explicitly anti-science and irrationalist movement. This perspective antedates the Sokal affair, corresponding to a series of inquisitorial books by Paul Gross and Norman Levitt, beginning with the book Higher Superstition: The Academic Left and its Quarrels with Science in $1994^{16}$ and it is reflected in the title of the 1995 meeting of the New York Academy of Science, The Flight From Reason. According to the various scientists, logicians, and philosophers speaking at the New York conference, the problem is that the grand and noble enterprise of science is under attack from feminist, deconstructive, and postmodernist critiques. The culprit is the disciplinary obscurantism indulged in by critics of science who fail to "understand" science: which failure yields complex and vague academic discourse. Accordingly, and this is the neatly emotional (not logical) conclusion found, the responsibility for an increasingly negative public perception of science and thus for the recent decline in federal support for science research - translating to a "war" on science - lies in the subversive effects of the cult of irrationalism in the academy or at least in the English departments of various universities. Nip the obscurantism, bad writing, and thought patterns of deconstruction and postmodernism in the bud, and social enthusiasm (and government funding levels) for the supercollider and other high ticket research programs will be up to speed in no time. No more social constructivist talk: bring back scientific reality.

I do not here propose to review the merits of the claim that only irrational forces could be behind the decline in federal support levels (the projected budget for the supercollider was on the order of billions rather than the physics routine measure of millions of dollars) not only because the arcana of the national economy has managed to elude comprehension from either conservative or liberal perspectives but also because, as the level of support for research on the human genome project makes very clear, that same potential public support seems undiminished, given the right appeal. Hence I address the myth of a war on science as a rhetorical fancy. For what is worth emphasizing is that both sides in the so-named science wars claim the side of science.

As Nelkin argues, the Sokal affair should be read in terms of the ideological program of the pro-science, anti-irrationalism movement. Yet, the anti-science movement that the anti-irrationalist faction is supposed to oppose lacks a manifest foundation in popular culture. That is, the charge is not that one or two voices critique science (these can surely be found) but rather that this critique has popular or mass support as well as undue public influence in the academy itself. But this is false. Academics are convicted pro-scientists, one and all. And the public (which includes the academy), far from being anti-science lionizes science as much as it ever did, agitating not for less research to solve social problems, such as AIDS or breast and prostate cancer, but for more and better research. If the public advocates support for alternative medical research, say, it is because the public believes in empirical efficacy, scientific tests, and the value of experiment far more than it believes in blindly submitting to AMA conservatism. In other words, what the public expects of science is that it be science, that is: that it employ scientific or experimental investigation rather than relying on paradigmatic authority. The public even turns to science and scientists for spiritual guidance, regarding Stephen Hawking as a cultural as well as an intellectual hero, like 
Albert Einstein. Both New Age movements and fundamentalist conservatives appeal to scientific authority in arguing their various positions - even those proposed against received scientific views. To claim an anti-science attitude lacks a basis in popular sentiment does not mean that I argue that the scientists' own anxiety is not genuine. Plato, inventing the kind of thinking that would make science possible, pointed to unregulated mythic beliefs, poetry, and particular musical modes as the greatest dangers to, or enemies of, rational society. In the same tradition, modern science long ago named the church or religious belief the incarnation of irrationality, and, borrowing the notion of martyrdom from the church, wrote its own story as a history of persecution. The conviction of the threat posed by ongoing religious hostility to science persists even where the scientific sensibility is dominant or unrivaled. (Just think of the pro-Darwinist perspective fueled in no small part by a knee-jerk response to creationism, a response happily ignoring the confidence on the part of the creationist not that science is wrong but rather that creationism is science.)

Such change as there has been in public sentiment toward science ought not be interpreted as a sign of distrust but the excess of confidence which exactly modern approbation and enthusiasm yields at the postmodern end of the day as the increasing disappointment and impatience - still not with the ideal of scientific progress but rather and only with its slow pace. Rather than an anti-science perspective, this disappointment results from the public's overweening trust in science. The value of science was never the production of pure knowledge; the strong cultural "good" of science (in Charles Taylor's economically informed sense of strong) has been all along inseparable from its technological embodiments or inventions. The rhetoric of scientific and technological progress has been a rhetoric of war against the foes of humankind: the war on cancer and poverty, the battle against HIV, the struggle against old age and death itself. The public that heard these claims subscribed to the implications of the metaphor, which implies a resolution or, ideally, a victory in a finite matter of time, accordingly the public happily assumes that the "scientific future" (with its attendant technological benefits) should have arrived by now.

This is the time of our inevitably postmodern discontent. Thus I have argued that any changed public perception of science results not from growing distrust but disappointed confidence. It is not that the public has lost its trust but that the public is increasingly eager to see science fulfill its promise.

\section{CHAOS AND PARADIGM}

For most commentators, the scandal is that Sokal's $S T$ article was accepted for publication. Yet the conviction (which is equally modern and postmodern) that scientific rationality represents the supreme intellectual perspective played a vastly more pernicious role in this case. Not anti-science sentiment on the part of the $S T$ editors but exactly pro-science prejudice worked to invite a scientist to offer a "hermeneutic" analysis in the first place. And this pro-science prejudice persists, after the fact, in the happy fantasy that all the trouble could have been avoided had real ("natural," mathematically sophisticated, not literary scholars and not "social") scientists been invited to referee Sokal's essay.

The problem is twofold: it is a problem of translation between conceptual schemes, as Donald Davidson or as Alasdair MacIntyre might say, or as the late Thomas Kuhn 
might (but would not) have said, of translation across incommensurable paradigms. For Sokal's difficulties began with his consummate inability (an inability typical of natural scientists) to attempt to comprehend the theoretical project of different social scientists' and cultural critics' reflections on the social and political conditions and implications of science, together with a flat-footed theoretical grasp of linguistic functions not to begin to speak of the meaning of hermeneutics. As some humanists are weak in mathematics and science, perhaps it is only fair that some physicists be deficient in the discursive complexities of rhetoric and thought. But what is to be said of and for those humanists on the postmodern side, who - in their enthusiasm for the literary value of the sheerest notion of information science, chaos theory, and indeterminacy (that most delicious of free-play terms) - have been so thoroughly seduced by those metaphors that researchers and theorists have, for their own part, appropriated to express scientific and mathematical relations? Attracted by the literary resonances of these metaphors, postmodernists have gone on to "detect" significances irrelevant to their use within the confines of science. Yet, pace N. Katherine Hayles and a mixed array of grad students, chaos theory per se neither uses nor entails reference to Hesiod's invocation of the primordial generativity of $\operatorname{chaos}{ }^{17}$ nor does it invite parallels with Joycean chassis much less the inventions of Thomas Pynchon. The belief in an openness to radical questions within such disciplines as physics and information science, explicitly asserted by JeanFrançois Lyotard and characterizing a "new" philosophy of science in the mind of Don Ihde and others, depends upon a naïve optimism betraying once again an ordinal and ordinarily modernist - an exactly pro-science - sensibility. The position of science as arbiter of truth and value from its inception and throughout modern culture - a status, as more than one critic has noted, akin to that of religion in premodern societies remains utterly unchallenged and all-too-modern a constant in postmodern thought. ${ }^{18}$

\section{HERMENEUTICS OF DECEPTION AND RHETORICS OF SUSPICION}

This supreme value of science ought to be kept in mind for the sake of an hermeneutic reading of the text Sokal offered to perpetrate his hoax. Sokal's $S T$ essay proposed to offer the reader "A Transformative Hermeneutics of Quantum Gravity." What was claimed in this essay, if read on its own terms and how, again on its own terms, ought the reader to have read this text? These are perfectly fine hermeneutic preliminaries to a reading of any text, but in the case of Sokal's averred hoax, it must be underscored that any reading is necessarily a re-reading in the way that most texts are not usually reread but simply read again and again (one returns to the text, like the Bible or Aristotle's Ethics, one does not re-read it so much as one reads it again, where rereading has the tone of the peremptory finality with which a disputed decision is re-read or a questionable exam is re-read). And to complicate the task of re-reading, the academic reader reflexively eschews a text retracted and stigmatized as a hoax by its author. That is the part in us that strains to see both duck and rabbit, that conscientiously reminds us that the two horizontal lines of the Muller-Lyer illusion are "really" equal in length. The intellectual's desire for truth is not unrelated to the schoolchild's fear of being tricked.

But, just to read his text, Sokal's stated intention or programme as expressed in his ST essay was exactly not a claimed argument and exactly not the affirmation of 
anything like a finished assertion. Thus in the introduction to his $S T$ article, Sokal cautions that his remarks are "of necessity tentative and preliminary." Thereby Sokal claims to offer no more than an experimental reflection, a venture, an exactly essayistic musing. He goes further as he builds his Trojan horse for the editors of Social Text: "I do not pretend to answer all the questions that I raise. My aim is, rather, to draw the attention of readers to these important developments in physical science and to sketch as best as I can their philosophical and political implications. I have endeavored here to keep mathematics to a bare minimum..." 19

The interpretive problem for an appropriate hermeneutic of this text is not then at issue, given Sokal's prefatory disclaimers. Armchair physics, just like armchair metaphysics, must be given a great deal of antinomic leeway. At issue, since Sokal does not claim that his text is conclusive but offers only "tentative and preliminary" speculation, is not the physicist's accuracy per se of what he reviews as his own articulation of "the philosophical and political implications" of certain "developments in physical science." Moreoever, Sokal offered to give not an account of those developments (as he cannot do in any case as he promises not to employ the very symbolic language that would be needed to do so, that is mathematics, the language of physical science) but an explicit interpretation offered perforce on the level of the dilletant, for Sokal's own formation is physics, not philosophy (not even analytic style philosophy), not political science or cultural criticism. Thus the "philosophical and political implications" he proposes are not those of an expert witness, where in recent recuperations of the history of the physical sciences, such expertise has come to be named not for its authoritative bravado but for the restraint, however calculated, of modesty.

Since Sokal does not propose to relate an expert scientific account of such "developments in physical science" but only to offer an interpretation of the same and employing disciplinary terms which are not his own, the text in question can only represent what philosophers since Plato quite technically name opinion. Since we are talking not about the "real world" of physical facts much less the "truth" as such but merely what Sokal professes to believe, it is essential that what is at stake is only the meta-textual - and withal non-hermeneutic - issue of whether Sokal meant (as he has since told us that he did not mean) what he said in his original essay, disclaimer and all. For apart from qualifiers routine enough in a provisional or speculative or experimental text, Sokal's only clear assertion, no matter whether earnestly intended or not, concerns his effort "to keep mathematics to a bare minimum." Here his claim is accurate enough for the subsequent text cites a single equation, $\mathrm{G}_{\mathrm{ij}}=8 \mathrm{GT}_{\mathrm{ij}}$. All things considered then, in his preface, Sokal does no more than give himself a warrant for a scientific extern's superficiality, renouncing the responsibility of his own specialist's rigor, and even duly warning the reader in advance against evaluative skepticism.

And yet if Sokal's $S T$ text begins with such tentative disclaimers, his $L F$ text takes an altogether different tone. Here, maliciously indignant, he announces the success of his ST hoax, claiming his right to serve as judge, jury, and executioner of whole disciplines other than his own. Yet nothing could be more obvious than that Sokal fails to understand his own sentences - he seems to regard his disclaimers as the equivalent of protocol statements in co-authored science texts, fatuously pro forma and adjunct to the report of the text as such - nor does he seem to comprehend the point of reflective 
critique. In essence, Sokal has no sense of the complex nature and range of the kind of things one can do with words. For texts proposed as speculative and critical, drawing the implications assessed in the author's view as "philosophical and political" are offered for the similar judgment of the reader's assessment of the same. Such nonassertoric texts do not report fact but invite further reflection; as readings of possibility, they are submitted to question. Such texts are under no compulsion to follow the logic of a physicist, particularly one who does not mean what he says. That is, although Sokal's text is presented under the aegis of a physicist's authority (this applies to both $S T$ and $L F$ texts), his $S T$ text does not argue on the basis of authority because it does not argue. Speculative, interpretive texts exceed authorized limits as exactly alternate readings. While meaningful discourse need not (although it may well) observe ordinary patterns of logic, it is a capital if also a paradoxical and inevitably obscure point that philosophical speculation does not always do so. And it is salutary to add that reflection on the fundamental value of logical constructions cannot do so. It is for this reason from Nietzsche to Davidson (never mind Duhem and Quine and scholars of mathematical and formal systems can add other names beyond Gödel and Turing) that a critique of logic and truth cannot be conducted on the ground of logic or truth. It is for this reason that Nietzsche wrote in "tissues" (in aphorisms and patterned discussions, ranging contradictory points in productive tension): "the problem of science," as Nietzsche put it, "cannot be recognized in the context of science." 20 This together with Nietzsche's penchant for inconsistency and explicit self-contradiction, is usually taken to mean all manner of things - not one of them good with respect to Nietzsche's scientific qualifications - but, in the current context, Nietzsche's claim is reasonable enough. All it entails is that the problem of science is ineluctably philosophical not scientific. We need to hear from philosophers on the problem of science - not from physicists. And when I say this I am very aware that this claim flies in the face of an old conviction of the very young discipline that is the philosophy of science (a discipline, notably, that did not exist as such in Nietzsche's day). This is the conviction that to philosophize on science one ought to be a scientist oneself (this is an ideal prerequisite as, however much they may aspire to be regarded on the same level, philosophers of science typically are not scientists). Yet I have argued elsewhere that Nietzsche's point is not without substance and that to the extent that the scientist Ernst Mach philosophised about Knowledge and Error, as indeed he did, to that same extent, he too, like Ludwik Fleck, was a philosopher. Patrick Heelan's fine lattice of languages and discourse communities illustrates something of the way one wears such different hats, not simultaneously, and not merely cumulatively - that is: what is phenomenological about it, to borrow Bob Crease's language, is the aletheic dimension - to use the only word, regrettably Heideggerian, we can have for the intuitively real (phenomenological) but counter-intuitive aspect of any revelation of truth as a occluding focus or emphasis that is always and also concealing or distraction.

While in $L F$ Sokal challenges the editors of $S T$ for failing to check the accuracy of his claims about the "new" physics' research standards, the editors of $L F$ clearly granted him the same leeway, clearly unchallenged, with respect to the "new" physics as with his use of the coordinate and not scientific but patently philosophic terms subjective (by which he may mean relative, if we adopt the interpretive generosity that Sokal attacks) and objective (by which he means something vague yet commanding enthusiasm). When 


\section{BABETTE E. BABICH}

Sokal asserts that there is an objective world, he apparently means to speak of a world real and independent of the knower and of the knower's capacity and way of knowing. But there is a difference of a whole philosophical kind between the claim that we cannot know the world (real, true, and objective) except on the terms of our capacity to know the (real, true, objective) world and the claim that there $i s$ no world. The difference has to do with the transformation of understanding involved in speaking of the real world, the true world, following upon consideration of what it means to speak of knowledge and truth. This last is an issue demanding an epistemological sophistication rarely characteristic of scientists.

Without question, Sokal is an academic "mole" of precisely the kind necessary to an utterly fantastic or imaginary "war" between science and the supposed demons of postmodernism or feminism (which last is an odd place to find enemies as most "feminist" treatments of science and the philosophy of science are largely about enfranchisement - that is, getting more women in on the practice and thus in on the discourse of science - and far less about critique) or "the left" (thus Sokal's political sympathies with past leftist traditions are often mentioned to ensure his role as such a mole or else as vouching for his "moral" honesty). Yet assuming the mole's function is the only possible war-making tactic, just as mockery is the only weapon at the disposal of analytic philosophy contra continental approaches to philosophy (and as I practice the same from the other side). This is not because continental approaches are otherwise unapproachable, it is because, as in the case of most cold-wars, the battle has already been won and winning and losing sides have both been decided in advance. Given the institutional dominance of both science and its acolyte, analytic philosophy, any kind of "reasoned" debate would have to be conducted on the ground of (real: hard or true) science and this just because it is essentially and inevitably irrational to question the value of rationality. For this same self-referential reason, the task of critical reflection on science, on rationality and logic, is not at all the first or proper task of cultural and social criticism, thus it is not on evidence in the sort of work that generally appears in $S T$ or $L F$. Much less can the task be undertaken on the basis of sociological or anthropological studies of science, inasmuch as sociology and anthropology are and very much wish to be - see Bruno Latour's sorrowful recantation in his recent book, Pandora's Hope ${ }^{21}$ - part and parcel of the scientific enterprise. No one, as Nietzsche repeats the old proverb, can jump over his own shadow. A reflective inquiry into the nature of science, reason, or truth requires the resources not of literary or cultural critique, nor indeed of the social context of science, but only the resources of critical philosophy, if such a critique is indeed possible in an exclusively science-approbative climate such as our own. It is essential to add that just such a critique is presupposed by (although this has come to mean: foreclosed in) the very enlightenment ideal of science as such.

The point of this paradoxical coincidence is that those philosophers who make it their business to question science, or reason, or truth are routinely charged with the offense or crime of irrationalism and are accordingly re-categorized - at their Sunday best - as poets (Nietzsche), mystics (Heidegger and sometimes Wittgenstein), or romantics (all three). But this same categorization is also the basis for denigrating and excluding such perspectives. That I think such repudiation is wrong is by now clear, but my reasons are far from postmodern. Philosophy has long defined itself as the 
discipline of the rational, the science of science, the love of truth. But the philosopher, as lover of wisdom or truth, was from the first a seeker, a radical questioner, an inquirer after origins. Where the pursuit of truth is not to be confessional or devotional but much rather critical - that is: where it is possible not only to pursue the ideal of truth but always also to ask "Why truth?"- the philosophy of science cannot simply invoke the value of science as an unquestioned ideal but ought first to raise the question of science, in Nietzsche's words, "as problematic, and questionable." 22 This task has yet to be accomplished, but Nietzsche, Heidegger, and other nontraditional philosophers have at least made the project of a critical philosophy of science plausible. ${ }^{23}$

\section{AGAINST POSTMODERN SOPHISTICATION IN SCIENCE \& TECHNOLOGY}

The reason so many postmodernists believe that science is on their side is because they are persuaded, like everyone else in Western, which is to say, global society, that science is inherently liberating: science is conceived as free play - the sphere in which orthodoxies have no purchase. But this belief comes at the cost of a coopted conventionality. Any assumption of postmodern sophistication on the part of science and technology is illusory, yet this does not mean it is not an accidental misunderstanding. With deadly earnest levity and self-declared irony, the vision of postmodern sophistication promises to overcome the limitations of the modern idea of progress by means of what is "technically" called "playfulness." What is meant by this playfulness is modern, techno-jocularity - Feynberg style.

There is and there can be nothing like a postmodern perspective interior to science itself and this is essentially because the project of science is an ineliminably modern project. Hence there is no postmodern science as such. The project of science is not the reflection upon, not the thinking of, or theory of, but and only the consecration or certification of, knowledge. And science is non-self-reflexive because it is the only "episteme" in town. As science occupies the place once held by the church in Western society, so, whatever our politics and whatever our stand on global warming, pesticides, gene-altered grains, we all run to science for justification of our position. As the free thinker once said of the church, we have no choice but to love its poison. ${ }^{24} \mathrm{We}$ are all courtiers of truth, however awkward our rhetoric; we are all defenders of rational inquiry, no matter our critical suspicions. Hence we are bound to go, in Nietzsche's words, "straight into-the old ideal." 25

The critique of science cannot be conducted by social scientists - neither historians nor anthropologists, neither sociologists nor rhetoricians for the good and simple reason that all of these specialist scholars, "social" or not, are scientists themselves. Instead such critique, in order to be a critique must be the task of a philosophy prepared, for the sake of truth, reason, and science, to question rather than to assume the values of truth, rationality, and science. Facing that task, Nietzsche proposed to illuminate the project of science on the ground of art, and to consider art, in turn, in the light of life. Does this mean that science, like art, is a human invention? Does this make it, horror of horrors for Ian Hacking, a social construct $?^{26}$ Yes, and of course. But we ought not forget that social constructs, like art and like science, exceed in both influence and significance the cultural world that give them birth. The Vichian axiom that we can know only what we make does not mean, as Nietzsche' genealogical critique has taken pains to emphasize, that we already know what we have done. Still, this is not to say, to speak in the 
vernacular of an Alan Sokal, that there is an objective (really real) world apart from our knowledge of it. The question of the objective reality of the world apart from our knowledge of it is an absurdity. Not because it is patent that the objectively real world is given with or without the human knower - the very logic of the claim, of what it means for the world to be given without one to whom it would be given denies the possibility of the assertion - but because it makes no sense, to use yet another Nietzschean metaphor, to wonder about the way the world would appear if we could (as we cannot) cut our heads off and still take a look. ${ }^{27}$ The "really-objective" look of things is unknowable - not so far, not up until now - but intrinsically unknowable because the world as it can be known by human, subjective inquiry, however scientific, however objectively attuned, can only count as an object as such for a knowing subject.

It is not uniquely the role of science to prove the patently objective existence of an objective world. Medieval theologians could "prove" the existence of angels on the grounds of their necessity, much as current physicists demand or posit the existence of neutrinos to enforce modern theories of stellar evolution. The aether once consigned to the realms of romantic fancy by scientists seems poised to be reinstalled one day as the framework for the energies of the universe. Physicists and scientists generally have very simple notions of reality, truth, and objectivity, and (as social and historical studies of science attest) they are notoriously unreliable witnesses to their own practice. They are in a word, incompetent philosophers of science. But the reliability of scientists in accounting for science reflects a quite ordinary self-reflexive limit, and in any case the value of science is practical. Science is skilled labor and, in that sense, an art. Scientists know how to do things, but that does not mean that science has to do with thinking. For calculation is not about reflection; it is about the production of effects, within limits, for the sake of appearances. ${ }^{28}$

\section{CONCLUSION}

I began with a reference to jesting and the perspective that can aid such jests. Unlike Alan Sokal's, I fully intend the literal point of such provocations. Philosophy of the analytic and reigning kind does in general seek to model itself on the image of science, and physics now has adopted the pose (for the media, anyway) of wisdom. But why should physics neglect its own affairs to play the role of purveyor of meytaphysical truths or indeed to stage elaborate hoaxes? Little of moment has occurred in physics since 1925 - some would even argue that the great era of scientific achievement is not still to come and that that is not, as some popular science writers argue, because the truth has been discovered. And it may have made a difference for his scientific career that Werner Heisenberg, for example, enjoyed a classically traditional education, requiring that already as a young man he had read Immanuel Kant's reflections on the problem of space and time. Might Heisenberg's familiarity with philosophical concepts (as the very philosophical tradition of thinking hard and unthinkable questions, where philosophy is neither logic nor science nor art but a kind of love) not have been essential to his scientific work as well as his later popular essays on these very themes? It is fashionable to claim that Einstein was not a great expert in mathematics. But, like Heisenberg, Einstein enjoyed the broad education, including the study of philosophy, that is altogether missing in the formation of today's scientists, not only in physics but increasingly in biology (and this means medical science) as well. The mathematical or 
computer literacy required for the sake of practical proficiency in any given scientific discipline has come to replace the kind of conceptual literacy once taken for granted in the formation of an Einstein or a Heisenberg.

I am far from making a plea for courses on Shakespeare for Cosmologists. I argue for the special value of philosophical study in the education of scientists became that study is a step in the direction of learning how to think. Heidegger observed that science does not think; and before him, not only Nietzsche but also Descartes, who was a mathematician as well as a scientist and philosopher, emphasized the danger of assuming that thinking was a skill one did not need to learn. ${ }^{29}$ Science can learn to think. What a revolution thinking might be for science I do not pretend to say. But there is no way to thinking without philosophy.

Fordham University/Georgetown University

\section{ACKNOWLEDGMENTS}

The current essay was first presented to a meeting of intenational scholars focusing on Hermeneutics in the Philosophy of Science at Stony Brook in June of 1996. The essays presented during that conference, with the exception of the present essay, were subsequently published in a special issue of the journal, Continental Philosophy Review. The journal's editor expected to feature a previously solicited essay on Sokal in some still unspecified future issue and found the idea of more than one essay excessive. The original version of this essay was ultimately published in Common Knowledge 6/2 (September 1997): 23-33 and included a special note of gratitude to Patrick A. Heelan. A second, more popular revision of the essay has also appeared in Telos.

\section{NOTES}

I take this optimistic description from a correspondent at Cambridge University.

Alan Sokal, "Transgressing the Boundaries Toward a Transformative Hermeneutics of Quantum Gravity," Social Text, 46/47 14.1-2 (Spring/Summer 1996):217-52 (hereafter cited as ST). The bulk of the essay is comprised of citations from other authors, notably Luce Irigaray and Stanley Aronowitz, and fully half of the page range given corresponds to footnotes and references (231-52). Sokal's text is absent from Science Wars, ed Andrew Ross (Durham: Duke University Press, 1996), which reprints the essays in the original $S T$ issue with additions but only an obliquely casual reference to Sokal, his hoax, or its aftermath. "Preface," 14 . The silence of philosophers of science in the five years that have intervened remains striking. One has to cast in one's lot, and philosophers of science are anxious to ensure that their vote be counted along with Sokal - not Social Text.

Sokal, “A Physicist Experiments with Cultural Studies," Lingua Franca (May/June 1996): 62-64 (LF).

See comments on this in my introduction, "The Fortunes of Incommensurability" above.

See the first footnote to Ragnar Fjelland's essay above, or see any standard discussion of the Sokal hoax.

This is the more sobering implication and the point of the article by Mara Beller, "The Sokal Hoax: At Whom are We Laughing?" Physics Today (Sept. 1998): 29-34.

In a letter on the topic, Caws does not devote an essay to the theme.

8 Beller, loc. cit.

9 Steven W einberg, "Sokal's Hoax," New York Review of Books, 8 August 1996, 11-15. For a rare and insightful analysis of Weinberg's project and ambition see Alasdair MacIntyre's preface to the second volume of the two volume collection, Nietzsche and the Sciences: B. Babich, ed., Nietzsche, Epistemology, and Philosophy of Science (Dordrecht: Kluwer, 1999), xv-xvii.

10 See Lingua Franca (July/August 1996): 55-64 for a round of letters from assorted academics, including a four-page reply by Bruce Robbins and Andrew Ross, editor of the original Social Text issue. See Liz McMillen's review of the hoax and its aftermath in the Chronicle of Higher Education, 28 June 1996, A13.

11 Dorothy Nelkin, "What are the Science W ars Really About?" Chronicle of Higher Education, 26 July 1996, A52. See also Nelkin, "The Science Wars: Responses to a Marriage Failed" in Ross, Science Wars, 114-22, and Charles E. Rosenberg's review of Marcia Angell's Science on Trial ("The Silicon Papers," New York 
Review of Books, 14 July 1996, 9-10). A wryly oblique defense of "ironic" or postmodern science appeared in the July 16th issue of the New York Times, authored by John Horgan, senior writer at Scientific American and author of The End of Science

12 Ellen Willis, "My Sokaled Life: Or, Revenge of the Nerds," Village Voice 25 June 1996, 20-21.

13 W einberg's case works because, although he tactically cites Derrida on (of all things) relativity, he does not cite physicists' writing on the same theme.

${ }_{14}$ See Heidegger's comparison of the exigent training and sensitivity needed to understand a painting (of Paul Klee), poetry (he speaks of Trakl) and physics (he names Heisenberg), and the expectation that philosophy one might abandon the reticence that refrains from demanding immediate intelligibility. Martin Heidegger, Time and Being, trans. Joan Stambaugh (New York: Harper, 1977), 2.

15 Friedrich Nietzsche, Twilight of the Idols. Nietzsche further asks, "What really is it in us that wants "the truth'?" Beyond Good and Evil, I 1, trans. R. J. Hollingdale (Harmondsworth: Penguin, 1973), 15. That many scholars continue to fail to understand Nietzsche is nicely underscored in practice in Steve Fuller's contribution to the the present volume.

16 Paul R. Gross and Norman Levitt, Higher Superstition: The Academy Left and Its Quarrels with Science (Baltimore: Johns Hopkins University Press, 1994). See also Norman Hackerman and Kenneth Ashworth, Conversations on the Use of Science and Technology (Denton: North Texas University Press, 1996). For an extended, critical review, see Roger Hart, "The Flight from Reason: Higher Superstition and the Refutation of Science Studies," in Science Wars, 259-92.

17 For a discussion of this archaic meaning see my "Nietzsche's Chaos sive natura: Evening Gold and the Dancing Star," forthcoming: Portug. Revista filosofia. Most continentally minded discussions of chaos, like French pro-science enthusiasts Edgar Morin and Henri Atlan as well as younger scholars in the literary, cultural wake of Deleuze and Baudrillard and fractal fanxy do not take chaos in this more archaic sense. For an exception, see Jean Granier, La problème de la verité dans la philosophie de Nietzsche (Paris: Seuil, 1966).

18 Though for a reading of the subversive power of science as an agency of patriarchy and violence, and thus as inimical to leftist ideals, see the introduction and lead essay in Geraldine Finn's, Why Althusser Killed his Wife: Essays on Discourse and Violence (Atlantic Highland: Humanities Press, 1996).

19 Sokal, "Transgressing the Boundaries," 218. This qualifying introduction thus purported to offer the services of a physicist to champion the views of feminist and leftist critics on the ultimate meaning of quantum theory. The editors of $S T$ were not prepared to look such a flattering gift horse in the mouth.

${ }^{20}$ Nietzsche, The Birth of Tragedy, “Attempt at a Self-Criticism," par.2, trans. Walter Kaufmann (New York: Vintage, 1967), 18.

21 Bruno Latour, cited, with Hacking, in Babich, "The Fortunes of Incommensurability" above.

22 Nietzsche explains this as his own achievement, articulating "the problem of science itself, science considered for the first time, as problematic, as questionable" ( Ibid.).

23 See my Nietzsche's Philosophy of Science (Albany: State University of New York Press, 1994) and the two volumes, Nietzsche Theories of Knowledge and Critical Theory and Nietzsche, Epistemology and the Philosophy of Science, Babich, with R. S. Cohen, ed., Boston Studies in the Philosophy of Science (Dordrecht: Kluwer, 1999).

${ }^{24}$ Cf. Nietzsche, On the Genealogy of Morals, trans. W. Kaufmann (New York: Vintage Book, 1969), I,

9.

25 Nietzsche, Genealogy of Morals, III, 25. Translation modified.

26 See Ian Hacking's post-factum effort to retrieve his own words from the tender mercies of more cavalier readers, The Social Construction of What? (Cambridge: Harvard University Press, 1999).

${ }_{27}$ This charming image is Nietzsche's Kantian variant: "We behold all things through the human head and cannot cut off this head; while the question nonetheless remains what of the world would still be them if one had cut it off." Human, All Too Human, II, par. 29, trans., R. J. Hollingdale (Cambridge: Cambridge University Press, 1986), 15.

28 This is the practical conditionality that yields Nietzsche's best proposal for a philosophy of science: "to look at science in the light of art, but at art in the light of life." Birth of Tragedy, 19.

29 Martin Heidegger, What is Called Thinking, trans. J. Glenn Gray (New York: Harper \& Row, 1968), 8. See the beginning reflections of Rene Descartes, A Discourse on Method, Part One. 